\title{
ПРАВОВА ПОЛІТИКА У СФЕРІ ІННОВАЦІЙНОї ДІЯЛЬНОСТІ: АДМІНІСТРАТИВНО-ПРАВОВИЙ ВИМІР
}

\begin{abstract}
ГУЛАК Любов Степанівна - кандидат юридичних наук, доцент, доцент кафедри адміністративного та інформаційного права Національного університету «Јьвівська політехніка"

МАЛЕЦЬ Марта Романівна - асистент кафедри адміністративного та інформаційного права Національного університету «Львівська політехніка»
\end{abstract}

DOI 10.32782/LAW.UA.2020.3.18

В статье рассмотренъ вопрось правовой политики в сфере инноваиий и интеллектуальной собственности. Анализируются вопросъ становления и развития законодательства, регулирующего инновационную деятельность и интеллектуальную собственность в Украине, рассматриваются вопросъ административно-правового регулирования инновационной деятельности и интеллектуальной собственности. Определено состояние административно-правовой охранъ сфберь интеллектуальной собственности как основного ялемента инновационной деятельности. Представлен анализ административноправовъх основ формирования и реализачии государственной политики в сбере инновационной деятельности. Систематизированъ основные мотивационнъе инструментьи, которвие могут бълть использованъ для повъишения вђбективности действующего законодательства в указанной сфере. Подчеркивается, что правовой культуры по правам интеллектуальной собственности, защить прав интеллектуальной собственности может обеспечиваться именно в процессе инновационной деятельности. Определенъ направления правовой политики, направленной на активизацию инновационного развития через развитие охранъ и зашить интеллектуальной собственности как составной инновационной деятельности.

Отмечено, что инновационная политика вълтупает составляющей сощиально- экономической $и$ правовой политики, направленная на стимулирование интеллектуальной деятельности, создает предпосъики для эфбективного развития инновационной системъ государства. Право является инструментом регулирования общественньх, в частности экономических отношений. Эбббективность права в регулировании экономических отношений зависит и от того, насколько полно оно отражает экономические потребности общества.

Ключевъе слова: правовая политика, инновация, инновационная деятельность, интеллектуальная собственность, инновационное развитие, правовое регулирование.

Постановка проблеми

В умовах європейської інтеграції та інформаційного суспільства, що формується увагу вчених, які представляють різні галузі наукового знання, приділяється інноваціям як матеріалізованим результатам інтелектуальної діяльності. Під інноваційною діяльністю розуміється сукупність взаємопов'язаних дій зі створення, освоєння та поширення інновацій, яка складається 3 низки послідовних стадій, регулюється різними нормами права: цивільного, адміністративного, фінансового, податкового, трудового та інших галузей національної системи права. Виходячи 3 цього, інноваційна діяльність становить міжгалузевий комплексний інститут. 


\section{Стан дослідження}

Загальні та окремі питання правової політики у сфері інновацій та інтелектуальної власності розглядали в працях вчені: В. Б. Авер'янов, В. М. Бевзенко, А. А. Борко, М. Г. Вербенський, К. Ф. Гуценко, I. В. Зозуля, Н. В. Камінська, Т. О. Коломоєць, В. К. Колпаков, А. Т. Комзюк, К. Б. Аевченко, В. Я. Малиновський, Р. С. Мельник, О. І. Миколенко, I. І. Сидорук, В. А. Синчук, О. Ю. Синявська, О. А. Соколенко, С. Г. Стеценко, Ю. С. Шемшученко та ін. Ці вчені зробили значний вклад у розвиток проблем правового регулювання у контексті адміністративного права. Але в умовах адаптації національного законодавства до вимог Европейського Союзу низку питань зазначеної теми залишаються дискусійними.

Мета статті - дослідження правової політики у сфері інновацій та інтелектуальної власності.

\section{Виклад основного матеріалу}

Ефективна інноваційна діяльність $є$ одним з пріоритетних напрямів розвитку держави. Це твердження підтверджують прийняті програмні документи щодо розвитку інноваційного середовища в країні. Правова політика у сфері інновацій - це складова державної науково-технічної та промислової політики, метою якої є формування економічних умов для виведення на ринок конкурентоспроможної інноваційної продукції.

Інноваційна політика виступає складовою соціально-економічної та правової політики, спрямована на стимулювання інтелектуальної діяльності, створює передумови для ефективного розвитку інноваційної системи держави. Право є інструментом регулювання суспільних, зокрема економічних відносин. Ефективність права в регулюванні економічних відносин залежить і від того, наскільки повно воно відображає економічні потреби суспільства.

Державна інноваційна політика значною мірою складається 3 різноманітних планів, стратегій і програм. Це положення пояснюється тим, що правове регулювання інноваційної діяльності грунтується на моделюванні майбутніх суспільних відносин, ніж закріплює вже сформовані відносини. Зазначена особливість цього виду правовідносин визначає більш тісний зв'язок правового регулювання та правової політики саме у сфері інтелектуальної діяльності та інновацій.

У літературі, під правовою політикою у сфері інновацій розуміють науково обгрунтовану, послідовну, системну діяльність державних і недержавних структур, спрямовану на визначення тактики та стратегії правотворчості у сфері інновацій, створення соціально-правової інфраструктури реалізації інтелектуальних прав громадян і організацій, формування у наукових і юридичних кадрів спеціальних правових компетенцій, що відповідають запитам інноваційного розвитку.

Правова політика у сфері інновацій покликана поєднувати публічно-правові та приватно-правові інтереси може бути виражена в таких формах: правотворча політика; політика реалізації права; політика інтерпретації права; політика правової освіти; правоохоронна та правозахисна політика.

Правотворча політика у сфері інновацій - це науково обгрунтована, послідовна та системна діяльність органів державної влади, органів місцевого самоврядування, інститутів громадянського суспільства щодо створення необхідних правових умов для ефективної інноваційної діяльності шляхом розробки і прийняття нормативної бази у галузі інноваційного розвитку.

Політика реалізації права у сфері інновацій становить науково обгрунтовану, послідовну та системну діяльність органів державної влади та місцевого самоврядування, недержавних структур зі створення правової інфраструктури з метою реалізації інтелектуальних прав.

Водночас, політика інтерпретації права у сфері інновацій становить науково обгрунтовану, послідовну, системну діяльність органів державної влади та місцевого самоврядування, недержавних структур щодо тлумачення чинного законодавства у сфері інновацій та охорони й захисту об'єктів інтелектуальної власності.

Окрім того, політика правової освіти у сфері інновацій становить науково обгрун- 


\section{Адміністративне право}

товану, послідовну, системну діяльність органів державної влади та місцевого самоврядування, недержавних структур щодо створення умов для підвищення якісного складу наукових і науково-педагогічних працівників, стимулювання припливу молоді в науку.

Правоохоронна політика в сфері інновацій спрямована на створення єдиного правового поля 3 охорони прав і законних інтересів суб'єктів інтелектуальної та інноваційної діяльності здійснюється завдяки впорядкованим діям уповноважених органів 3 виявлення або розслідування правопорушень, відновлення порушених прав, захисту правопорядку, наглядом за додержанням законності, активною і цілеспрямованою взаємодією [1, с. 150].

Під правозахисною політикою розуміють науково обгрунтовану, послідовну та комплексну діяльність державних і недержавних структур щодо оптимізації захисту прав людини, вдосконалення засобів і способів захисту, формування повноцінної правозахисної системи.

Сьогодні загальновизнаними є два базові підходи до визначення поняття інновація. У широкому сенсі під інновацією розуміється результат творчої діяльності, застосування якого призводить до істотних змін у функціонуванні системи.

У вузькому сенсі інновація - це нове рішення технічного завдання, здійснене в практичній діяльності. Ознаками інновацій виступають: новизна, сукупність властивостей, що свідчать про кардинальні зміни об'єкта, внаслідок яких задовольняється нова потреба або задовольняється по-новому наявна потреба, знижуються витрати тощо; спрямованість на конкретне перетворення, мається на увазі не різноманітні не зв'язані нововведення, що виникають миттєво під впливом подій, а тільки ті, які мають на меті конкретне перетворення; зв'язок $з$ інтелектуальною діяльністю, тобто інновації є результатом науково-дослідної або іншої інтелектуальної діяльності; виробнича застосовність, можливість і здатність застосування інновації і отримання на їі основі нового або вдосконалення продукту; комерційна реалізація, тобто задоволення споживчого попиту, наявного на ринку, інакше кажучи, важливою ознакою інновацій є можливість комерціалізації інноваційного продукту, його залучення в економічний обіг метою отримання прибутку; отримання економічної вигоди або створення умов для іï отримання; ефективність, спрямованість на вдосконалення процесу виробництва.

У контексті закону «Про інноваційну діяльність» інновації - це новостворені (застосовані) і (або) вдосконалені конкурентоздатні технології, продукція або послуги, а також організаційно-технічні рішення виробничого, адміністративного, комерційного або іншого характеру, що істотно поліпшують структуру та якість виробництва i (або) соціальної сфери [2]. Інновацію слід розглядати у вигляді родового поняття, що об'єднує охоронювані результати інтелектуальної діяльності, які виникають у результаті створення нововведень, нових технічних рішень, коли вони виражені в об'єктивній формі і можуть задовольняти суспільні потреби.

Під інновацією слід розуміти результат інтелектуальної праці, що одержав втілення у вигляді нового або вдосконаленого продукту (товару, робіт, послуг), технічного процесу, який володіє комерційним потенціалом.

С. Г. Гордієнко і О. В. Соснін, розглядаючи сутність, зміст, практика інноваційної діяльності та захисту інтелектуальної власності в Україні зазначають, що інноваційна діяльність $є$ підставою створення нового знання та інтелектуальних продуктів, визнаних на державному, регіональному та світовому рівнях, на які поширюється право власності [3, с. 245].

Інноваційною діяльністю $є$ виконання робіт і (або) надання послуг, спрямованих на створення i організацію виробництва принципово нової або з новими споживчими властивостями продукції (товарів, робіт, послуг), з одного боку. 3 іншого боку, інноваційна діяльність - це створення нових або модернізація наявних способів (технологій) виробництва продукції, іiї поширення та використання.

У сучасних джерелах виділяють такі основні юридично значимі ознаки інновацій: $є$ результат наукової творчості, як пра- 
вило, наявного у вигляді об'єкта інтелектуальної власності; виступає у вигляді продукту, технології, послуги, інших матеріальних форм, здатних до відтворення; призначена для задоволення потреб суспільства. Водночас інноваційна діяльність вимагає осмислення основних понять і законів економіки.

Характерною особливістю розвитку наукового знання $\epsilon$ створення своєрідного поля перетину, активної взаємодії і взаємопроникнення різних наук, теоретичних концепцій і методів пізнання, що збагачує їх і приносить виключно плідні результати.

Аегітимне визначення того, яку діяльність слід вважати інноваційною, подано в законі «Про інноваційну діяльність». У літературі класифікують інновації за різними підставами, виділяючи різноманітні види інновацій. Продуктовими інноваціями виступає новий або істотно поліпшений продукт. Процесними інноваціями є впровадження технологічно нових процесів виробництва або їх вдосконалення. Маркетингові інновації - це впровадження нового методу маркетингу. Організаційні інновації - це впровадження нових організаційних методів.

За рівнем новизни виділяють такі види інновацій: базисні інновації і поліпшуючі інновації. Базисні інновації $\epsilon$ нововведення, засновані на докорінні зміни, на фундаментальних науково-технічних результатах, спрямовані на впровадження принципово нових технологій. Поліпшуючі інновації виражаються у створенні нових матеріалів i машин, вони спрямовані на поліпшення параметрів продукції, що випускається, послуг, що надаються, технологій, що використовуються.

О. В. Захарова та I. С. Барбанова під інноваційною діяльністю розуміє сукупність скоординованих дій, робіт і послуг зі створення і практичного використання нової або удосконаленої продукції або нового або вдосконаленого процесу [4, с. 56].

Інноваційна діяльність складається 3 таких стадій технологічної реалізації: розробка фундаментального наукового знання; створення прикладного наукового знання; застосування отриманого наукового знання для створення зразка результату інноваційної діяльності; закріплення прав на ре- зультат інтелектуальної власності; впровадження результату інноваційної діяльності у виробництво; комерціалізація результату інноваційної діяльності та отримання прибутку.

Правова політика у сфері інновацій має бути націлена та всіляко сприяти створенню і впровадженню інновацій у державі, стимулювати інноваційну та інтелектуальну діяльність. Результатом такої інноваційної політики повинні виступати нові явища соціальної дійсності, такі як: технопарки, технополіси, бізнес-інкубатори, особливі економічні зони, територіально-галузеві виробничі кластери, інші об'єкти інноваційної інфраструктури.

Необхідно підкреслити, що технополіси набули досить широкого розповсюдження в розвинених країнах Європейського Союзу та в Японії, причому відбувається подальший поступальний розвиток. В Україні проголошено прагнення держави до всебічного розвитку інновацій, державну підтримку різних форм стимулювання творчої діяльності, мінімізація сировинної залежності. Стратегія розвитку сфери інноваційної діяльності на період до 2030 року визначає курс на інноваційний розвиток як пріоритетний напрям розвитку України [5].

Правова політика держави з метою всебічного розвитку інноваційної діяльності може включати низку стимулів, зокрема, фінансово-правові стимули: фіскальні пільги, пов’язані з податковим стимулюванням; спеціальний пільговий субсидіарний режим гарантії від несприятливої зміни законодавства про податки та збори; бюджетні асигнування; ефективний доступ до фінансових ресурсів; інвестиційний податковий кредит.

Дуже важливим моментом 6 необхідність створення сприятливих умов у державі для залучення інвестицій. Особлива роль тут належить інфраструктурі інновацій, передусім, венчурним інвестиційним фондам. Необхідно створити такі умови, при яких базові фундаментальні дослідження проводилися не стільки за рахунок бюджетного фінансування, а в більшій мірі за рахунок приватних інвестицій, великих корпорацій, виробників і споживачів наукомісткої продукції. Для ефективної реалізації тако- 


\section{Адміністративне право}

го приватно-державного партнерства слід створювати спеціальні програми прямого співробітництва держави та приватного бізнесу.

Метою державної інноваційної політики має стати створення умов для сталого економічного зростання, виходу інноваційної продукції на внутрішній і зовнішній ринки за рахунок підвищення технологічного рівня та конкурентоспроможності виробництва.

Юридичними підставами правової політики в сфері інновацій виступають міжнародні та внутрішньодержавні нормативноправові акти, що регламентують питання здійснення інноваційної діяльності та окремі правозастосовні акти.

В Україні правова основа інноваційної діяльності базується на законі «Про інноваційну діяльність». Але відсутній системний підхід щодо взаємного доповнення нормативно-правового регулювання у сфері інноваційної та інтелектуальної діяльності. На нашу думку, відсутні не просто будь-які нормативно-правові акти, немає системності підходу, розуміння сутності та структури предмета правового регулювання, всеосяжного охоплення організованих відносин. У зв'язку з цим, становлення правової політики України в сфері інновацій у контексті охорони та захисту інтелектуальної власності відбувається в умовах недостатньо сформованої нормативно-правової бази.

Законодавчий масив про інноваційну діяльність виглядає як самостійний правовий блок, практично не пов'язаний $з$ уже існуючими і цілком усталеними в системі права інтелектуальної власності утвореннями. Курс на інноваційний розвиток України як важливий напрям правової політики держави закріплюеться в Цілях сталого розвитку України на період до 2030 року як моделі розвитку держави [6].

Для досягнення зазначених цілей необхідно вдосконалення нормативно-правової бази, на іiі основі, створення ефективного механізму реалізації конституційно закріпленого права громадян на творчу діяльність.

Необхідно внести зміни та доповнення до цілої низки законодавчих актів 3 метою узгодження, розробити тезаурус в сфері інноваційної діяльності. Слід створити комплекс нормативно-правової бази, який враховував би всі правовідносини, що можуть потенційно виникнути при здійсненні інноваційної діяльності.

Державна політика в інноваційній сфері заснована на державних стратегіях і програмах розвитку в різних галузях у рамках єдиної правової політики у сфері інновацій. Правова політика у сфері інновацій встановлює цілі та пріоритети суспільного розвитку, визначає сучасне становище питання, сучасні проблеми та подальші перспективи вдосконалення інноваційного потенціалу країни.

Потрібний комплексний, системний підхід до формування інноваційного середовища й інноваційної інфраструктури, до ефективного державного управління інноваційною системою як результат, широка інтеграція у світове конкурентне середовище. Для досягнення зазначених орієнтирів і реалізації заявлених завдань необхідне прийняття цілої низки, політичних і правових актів. Важливим є створення життєздатної системи органів державного та місцевого рівнів 3 певними завданнями та повноваженнями в інноваційній сфері.

Державна інноваційна політика повинна формуватися, виходячи з цілей не тільки організації та розвитку, а й заохочення творців інноваційної продукції. Правову політику держави у сфері інновацій слід визначати як складову державної науково-технічної та промислової політики, як сукупність здійснюваних соціальних, економічних і інших заходів. Зазначені заходи повинні бути спрямовані на формування умов для всебічного розвитку виробництва конкурентоспроможної інноваційної продукції на базі передових досягнень науки та техніки.

Заходи повинні сприяти підвищенню частки такої продукції, так само як створення системи просування та реалізації інноваційної продукції та послуг на європейському економічному просторі, на світовому ринку. Правова політика в сфері інновацій України значною мірою за змістом складається з різноманітних проєктів, різного рівня планів i прогнозів перспективного розвитку. 
Базові основи, що визначають цілі та пріоритети правової політики у сфері інновацій містяться в політико-правових документах - концепціях або стратегіях. Цілями та пріоритетами державної правової політики у сфері інновацій є всебічний розвиток інноваційної системи, формування механізму інноваційного розвитку регіонів, підвищення конкурентоспроможності суб'єктів інноваційної діяльності, зростання обсягів інноваційної продукції.

Слід враховувати нагальну потребу створення сприятливого клімату та підтримки учасникам інноваційної діяльності, науково-технічної творчості, розвиток освітніх програм, системи підвищення кваліфікації фахівців з інтелектуальної власності, освоєння практичних навичок ведення підприємницької й іншої господарської діяльності в інноваційній сфері.

Говорячи про державні стратегії та програми розвитку в рамках правової політики в інноваційній сфері, важливо зазначити, що формування ефективної національної інноваційної системи виступає одним із пріоритетних напрямів державної політики України.

Стратегії та програми розвитку у галузі інтелектуальної власності в інтересах технологічного ринку України визначають цілі та пріоритети державної політики у сфері інтелектуальної власності, встановлює довгострокові орієнтири розвитку національної системи інтелектуальної власності. Цілями зазначених стратегічних планів заявлені розробка комплексу правових, організаційно-економічних та інституційних механізмів у галузі інтелектуальної власності, розвиток промислового наукоємного виробництва, примноження науково-технічного потенціалу країни, створення та введення в цивільний обіг конкурентоспроможної інноваційної і високотехнологічної продукції, формування сприятливого економічного клімату, розвиток інноваційних підходів.

У їх основі містяться положення Стратегії розвитку сфери інноваційної діяльності на період до 2030 року, Цілей сталого розвитку України на період до 2030, рекомендацій Всесвітньої організації інтелектуальної власності щодо формування національних стратегій у галузі інтелектуальної власності та рекомендацій Парламентських слухань на тему «Побудова ефективної системи охорони інтелектуальної власності в Україні» [7].

Як зазначає О. П. Орлюк, досліджуючи проблеми та завдання освіти з інтелектуальної власності у системі вищої освіти України, державна програма розвитку освіти передбачає організацію підготовки нового покоління управлінських кадрів у сфері інтелектуальної власності в провідних міжнародних університетах і стажування фахівців у патентних відомствах країн Свропейського Союзу [8, с. 150].

Пріоритетним напрямом інноваційного розвитку є створення умов для формування здатності до творчого, критичного мислення, підприємливості, креативності, наявності навичок і вміння ефективно працювати у творчому середовищі. Важливо сформувати правову культуру у сфері інтелектуальної власності, здатність до ділового та професійного спілкування у сфері інноваційного розвитку. 3 розвитком науково-технічного прогресу суспільні відносини вступають у нову сферу, в Інтернет, який впливає на всі аспекти соціального життя. По суті, народжується новий вид цивілізаційних відносин, який трансформує звичний уклад: змінюється зміст праці, істотні перетворення відбуваються в культурі й освіті [9, с. 150].

До пріоритетних напрямів інноваційного розвитку відноситься: створення системи заохочень і гнучких регуляторів 3 метою вдосконалення механізму, що дозволяє здійснювати фінансову, організаційну та консультаційну підтримку ефективних результатів інноваційної діяльності на всіх стадіях життєвого циклу; активізація підтримки виходу на зовнішні ринки інноваційних високотехнологічних компаній; удосконалення нормативно-правової бази у сфері інноваційної діяльності; створення системи центрів колективного користування у сфері творчих індустрій, формування відкритої інформаційної системи моніторингу якості надання адміністративних послуг у галузі інтелектуальної власності та інновацій; розробка та реалізація програм розвитку регіональної інноваційної інфраструктури, впро- 


\section{Адміністративне право}

вадження нових технологій і формування територіальних структур.

Сучасний стан в інноваційній сфері характеризується збереженням застійних тенденцій і невиправданого адміністрування, 3 одного боку, з іншого, в останні роки країна втратила позиції лідера в інтелектуальній сфері, що дозволяє зробити висновок про низьку ефективність національної системи у сфері інновацій та назрілу необхідність у реформуванні. Особливостями завтрашньої системи державного управління повинні стати самостійність і відповідальність, динамічний рух уперед, проходження загальної ідеології європейської інтеграції країни, ефективне використання ресурсів, неординарні рішення, підтримка ініціативи та інновацій, змінюваність кадрів, компетентність.

\section{Висновки}

Державні стратегії та програми розвитку інновацій повинні грунтуватися на перспективній правовій політиці в цій галузі, визначати цілі і пріоритети розвитку, стимулювати розвиток і впровадження інноваційних технологій. 3 метою дослідження юридичних аспектів інноваційних явищ і процесів, у літературі пропонується виробляти відповідний категоріальний апарат. Заявлена потреба в чіткому визначенні таких понять: інноваційні явища, інноваційна діяльність та низки інших. Інноваційні явища слід розуміти як кінцевий результат успішного впровадження нових елементів, змін форми якоїсь системи 3 метою підвищення iii ефективності та оптимального вирішення нагальних соціально значущих завдань. Інноваційна діяльність є істотне нововведення, докорінна модернізація певних галузей життедіяльності суспільства, спрямованих на підвищення дієвості та значне збільшення цінності управлінських систем.

Під правовою політикою у сфері інновацій пропонується розуміти науково обгрунтовану, послідовну, системну та злагоджену роботу державних структур і інститутів громадянського суспільства, спрямовану на формування правових передумов для ефективної інноваційної діяльності шляхом прийняття відповідних нормативно-правових актів, вибудовування дієвого механізму правозастосування в галузі охорони і захисту інтелектуальної власності, підготовки кваліфікованих кадрів для роботи в інноваційній сферi.

Правова політика у сфері інновацій має бути націлена на правове забезпечення всебічного інноваційного розвитку країни в рамках єдиної стратегії та тактики, що включає закони, стратегічні плани та концепції розвитку. Це пояснюється тим, що правове регулювання інноваційної діяльності грунтується на моделюванні майбутніх суспільних відносин і направлено на стимулювання інтелектуальної діяльності у всіх сферах життєдіяльності держави.

\section{Аітература}

1. Ковалів М. В., Есімов С. С., Лозинський Ю. Р. Правове регулювання правоохоронної діяльності: навчальний посібник. Аьвів: АьвДУВС. 2018. 323 с.

2. Про інноваційну діяльність: Закон України від 04.07.2002 р. № 40-IV. Відомості Верховної Ради Украӥни. 2002. № 36. Ст. 266.

3. Інформаційне суспільство в світі та Україні: проблеми становлення та закономірності розвитку: колективна монограбія. Запоріжжя: ЗДІА. 2017. 282 с.

4. Захарова О. В., Барбанова I. С. Нормативне підгрунтя активізації інноваційного розвитку регіонів України. Економіка і організація управління. 2019. № 1 (33). С. 53-63.

5. Про схвалення Стратегії розвитку сфери інноваційної діяльності на період до 2030 року: Розпорядження Кабінету Міністрів України від 10.07.2019 р. № 526-p. URL: https://zakon. rada.gov.ua/laws/show/526-2019-\%D1\%80

6. Про Цілі сталого розвитку України на період до 2030 року: Указ Президента України від 30.09.2019. р. № 722/2019. URL: https://zakon.rada.gov.ua/laws/show/722/2019

7. Парламентські слухання на тему: «Побудова ефективної системи охорони інтелектуальної власності в Україні». Верховна Рада України. URL: https://rada.gov.ua/news/ Novyny/186120.html

8. Орлюк О. П. Освіта з інтелектуальної власності у системі вищої освіти України: проблеми та завдання. Теорія $і$ практика інтелектуальної власності. 2019. № 6. С. 148-159. 
Гулак Л.С., Малець М.Р. - Правова політика у сфері інноваційної діяльності...

\section{АНОТАЦІЯ}

у статті розглянуто питання правової політики у сфері інноващій та інтелектуальної власності. Аналізуються питання становлення та розвитку законодавства, що регулюе інноваційну діяльність та інтелектуальну власність в Україні, розглядаються питання адміністративно-правового регулювання інноваційної діяльності та інтелектуальной власності. Визначено стан адміністративно-правової охорони сфери інтелектуальної власності як основного елемента інноваційної діяльності. Подано аналіз адміністративно-правових засад бормування та реалізачї державної політики у сбері інноваційної діяльності. Систематизовано основні мотиваційні інструменти, що можуть бути використаними для підвищення ебективності чинного законодавства у вказаній сфері. Підкреслюється, що підвищення правової культури щодо прав інтелектуальної власності, захисту прав інтелектуальноӥ власності може забезпечуватися саме у процесі інновачійної діяльності. Окреслено напрями правової політики, направленої на активізацію інновачійного розвитку через розвиток охорони та захисту інтелектуальної власності як складової інноваційної діяльності.

Наголошено, щзо інноваційна політика виступає складовою сочіально-економічної та правової політики, спрямована на стимулювання інтелектуальної діяльності, створює передумови для ебективного розвитку інноваційної системи держави. Право є інструментом регулювання суспільних, зокрема економічних відносин. Ефективність права в регулюванні економічних відносин залежить $i$ від того, наскільки повно воно відображає економічні потреби суспільства.

Ключові слова: правова політика, інноваиія, інновачійна діяльність, інтелектуальна власність, інновачійний розвиток, правове регулювання.

\section{SUMMARY}

The article considers the issues of legal policy in the field of innovation and intellectual property. The issues of formation and development of the legislation regulating innovation activity and intellectual property in Ukraine are analyzed, the issues of administrative and legal regulation of innovation activity and intellectual property are considered. The state of administrative and legal protection of intellectual property as the main element of innovation is determined. The analysis of administrative and legal bases of formation and realization of the state policy in the field of innovative activity is given. The main motivational tools that can be used to increase the effectiveness of current legislation in this area are systematized. It is emphasized that the increase of legal culture on intellectual property rights, protection of intellectual property rights can be provided in the process of innovation. The directions of the legal policy directed on activization of innovative development through development of protection and protection of intellectual property as a component of innovative activity are outlined.

It is emphasized that innovation policy is a component of socio-economic and legal policy aimed at stimulating intellectual activity, creates preconditions for the effective development of the innovation system of the state. Law is an instrument of regulation of social, in particular econom$i c$ relations. The effectiveness of law in regulating economic relations also depends on how fully it reflects the economic needs of society.

Key words: legal policy, innovation, innovative activity, intellectual property, innovative development, legal regulation.

9. Бортник Н., Єсімов С. Відносини в мережі Інтернет як об'єкт правового регулювання. Вісник Національного університету «\ъвівсъка політехніка». Юридичні науки. Аьвів: Вид-во Аьвівської політехніки, 2019. Вип. 6. № 22. С. 147-153. 